\title{
Kemampuan fiskal daerah dan pengaruh belanja daerah terhadap pertumbuhan ekonomi Kabupaten Tanjung Jabung Barat
}

\author{
Rahmad Suhendra*; Muhammad Safri; Adi Bhakti \\ Prodi Ekonomi Pembangunan, Fak. Ekonomi dan Bisnis,Universitas Jambi \\ *E-mail korespondensi: rahmadsuhendra@yahoo.com
}

\begin{abstract}
The purpose of this study was to determine and analyze 1) the proportion of regional expenditure in Tanjung Jabung Barat Regency; 2) regional fiscal capacity in West Tanjung Jabung Regency; 3) the ratio of regional financial independence of West Tanjung Jabung Regency; 4) the financial performance of the regional government of West Tanjung Jabung Regency and 5) the influence of regional spending on economic growth in the West Tanjung Jabung Regency. The data used in this study are secondary data. The analysis tool used is multiple linear regression. The results showed that the proportion of indirect expenditure to regional expenditure tended to decrease, while the proportion of direct expenditure to regional expenditure had an increase. The fiscal capacity of Tanjung Jabung Barat Regency for 11 years is still very lacking at the interval scale. The regional financial independence of West Tanjung Jabung Regency is in the low criteria. The regional financial performance of Tanjung Jabung Barat Regency is in the low and very low criteria. Regional expenditure influences economic growth in West Tanjung Jabung Regency.
\end{abstract}

Keywords: Fiscal, Financial, Performance

\begin{abstract}
Abstrak
Tujuan dari penelitian ini adalah untuk mengetahui dan menganalisis 1) proporsi belanja daerah di Kabupaten Tanjung Jabung Barat; 2) kemampuan fiskal daerah di Kabupaten Tanjung Jabung Barat; 3) rasio kemandirian keuangan daerah Kabupaten Tanjung Jabung Barat; 4) kinerja keuangan pemerintah daerah Kabupaten Tanjung Jabung Barat dan 5) pengaruh belanja daerah terhadap pertumbuhan ekonomi di Kabupaten Tanjung Jabung Barat. Data yang digunakan dalam penelitian ini merupakan data sekunder. Alat analisis yang digunakan adalah regresi linier berganda. Hasil penelitian menunjukkan proporsi belanja tidak langsung terhadap belanja daerah cenderung mengalami penurunan sedangkan proporsi belanja langsung terhadap belanja daerah mengalami peningkatan. Kemampuan fiskal Kabupaten Tanjung Jabung Barat selama 11 tahun masih dalam skala interval yang sangat kurang. Kemandirian keuangan daerah Kabupaten Tanjung Jabung Barat berada pada kriteria rendah. Kinerja keuangan daerah Kabupaten Tanjung Jabung Barat berada dalam kriteria rendah dan sangat rendah. Belanja Daerah memiliki pengaruh terhadap pertumbuhan ekonomi di Kabupaten Tanjung Jabung Barat.
\end{abstract}

Kata kunci: Fiskal, Keuangan, Kinerja

\section{PENDAHULUAN}

Tujuan otonomi daerah pada dasarnya adalah untuk mewujudkan pemerataan pembangunan dan hasil-hasilnya; meningkatkan kesejahteraan rakyat; menggalakkan 
prakarsa dan peran serta masyarakat; serta meningkatkan pendayagunaan potensi daerah secara nyata, optimal, terpadu, dan dinamis, serta bertanggung jawab sehingga memperkuat persatuan dan kesatuan bangsa, mengurangi beban pemerintah pusat dan campur tangan terhadap daerah dan memberikan peluang untuk koordinasi tingkat lokal atau daerah (Bastian, 2005). Reformasi keuangan daerah ini diharapkan mampu memacu pemerintah daerah otonom melaksanakan otonomi penuh.

Ciri utama suatu daerah yang mampu melaksanakan otonomi, yaitu (1) kemampuan keuangan daerah, artinya daerah harus memiliki kewenangan dan kemampuan untuk menggali sumber-sumber keuangan, mengelola dan menggunakan keuangan sendiri yang cukup memadai untuk membiayai penyelenggaraan pemerintahannya, dan (2) ketergantungan kepada bantuan pusat harus seminimal mungkin, agar pendapatan asli daerah (PAD) dapat menjadi bagian sumber keuangan terbesar sehingga peranan pemerintah daerah menjadi lebih besar. Kemampuan daerah otonom melaksanakan otonomi keuangan secara penuh dalam periode pendek diragukan, baik sebagai akibat kapabilitas daerah otonom yang tidak dapat berubah begitu cepat maupun sistem keuangan, yaitu pemerintah pusat tidak serta merta mau kehilangan kendali atas pemerintah daerah. Beberapa hal yang dapat menghambat keberhasilan pemerintah daerah melaksanakan otonomi, yaitu (1) dominannya transfer dan pusat, (2) kurang berperannya perusahaan daerah sebagai sumber pendapatan asli daerah (PAD), (3) tingginya derajat sentralisasi dalam bidang perpajakan, (4) kendati pajak daerah cukup beragam, ternyata hanya sedikit yang bisa diandalkan sebagai sumber penerimaan, (5) kelemahan dalam pemberian subsidi dari pemerintah pusat kepada pemerintah daerah.

Kemampuan pemerintah daerah dalam mengelola keuangan tercermin dalam Anggaran Pendapatan Belanja Daerah (APBD) yang menggambarkan kemampuan pemerintah daerah dalam membiayai kegiatan pelaksanaan tugas pembangunan, serta pemerataan dan keadilan dengan mengembangkan seluruh potensi yang dimiliki oleh masing-masing daerah.

Besarnya proporsi tersebut memberikan petunjuk bahwa pembangunan perekonomian daerah sangat dipengaruhi oleh posisi anggaran pemerintah pusat. Permasalahan yang dihadapi oleh pemerintah pusat terkait dengan anggarannya, akan langsung berpengaruh terhadap perekonomian daerah. Pengaruh pemerintah pusat terhadap daerah berjalan melalui mekanisme perimbangan keuangan antara pemerintah pusat dan daerah yaitu melalui dana perimbangan berupa transfer pemerintah pusat kepada daerah, Demikian pula dengan Kabupaten Tanjung Jabung Barat, dilihat dari sisi penerimaan daerah memiliki ketergantungan yang tinggi terhadap pemerintah pusat selama periode tahun 2005 - 2015 kontribusi pendapatan asli daerah (PAD) Tanjung Jabung Barat yaitu sebesar 4,30 \% sementara untuk dana perimbangan yang bersumber dari Dana Alokasi Khusus (DAK), Dana Alokasi Umum (DAU) dan Dana bagi hasil pajak/bukan pajak menunjukan proporsi yang sangat besar selama periode tahun 20052015 yaitu rata-rata sebesar 89,70\%. Hal ini menunjukkan ketergantungan yang tinggi Pemerintah Kabupaten Tanjung Jabung Barat terhadap pemerintah pusat dalam pembiayaan pembangunan di daerah. Sedangkan sisanya rata-rata 6,00 \% merupakan kontribusi pendapatan lain-lain terhadap total pendapatan daerah selama periode 2005 2015.

Sementara kalau dilihat dari kontribusi rata-rata besarnya dana belanja tidak langsung sebesar 41,40\% sementara belanja langsung mencapai 58,60 \%. Hal ini menunjukkan bahwa APBD Kabupaten Tanjung Jabung Barat lebih banyak digunakan untuk kepentingan publik dibandingkan dengan kepentingan aparatur, sehingga dengan 
demikian tujuan pembangunan untuk meningkatkan kesejahteraan masyarakat dapat dicapai melalui peningkatan pertumbuhan ekonomi. Dalam hal ini untuk Kabupaten Tanjung Jabung Barat sepanjang tahun 2005 sampai dengan tahun 2015 terus mengalami peningkatan pertumbuhan ekonomi dengan rata-rata pertumbuhan ekonomi per tahun sebesar $4,74 \%$.

Adapun tujuan dari penelitian ini adalah untuk mengetahui dan menganalisis 1) proporsi belanja daerah di Kabupaten Tanjung Jabung Barat; 2) kemampuan fiskal daerah di Kabupaten Tanjung Jabung Barat; 3) rasio kemandirian keuangan daerah Kabupaten Tanjung Jabung Barat; 4) kinerja keuangan pemerintah daerah Kabupaten Tanjung Jabung Barat dan 5) pengaruh belanja daerah terhadap pertumbuhan ekonomi di Kabupaten Tanjung Jabung Barat.

\section{METODE}

Untuk menjawab tujuan pertama dari penelitian ini yaitu untuk menganalisis proporsi belanja daerah Kabupaten Tanjung Jabung Barat tahun 2005-2015 maka digunakan analisis deskriftif, yang ditampilkan dalam bentuk data dan tabel, selanjutnya dilakukan analisis terhadap fenomena-fenomena yang terdapat dalam tabel tersebut. Untuk mengetahui proporsi belanja tidak langsung dan belanja langsung terhadap Belanja Daerah Kabupaten Tanjung Jabung Barat maka digunakan formulasi sebagai berikut: (Kakisina dan Rumansara, 2000).

Rumus proporsi belanja tidak langsung:

$\mathrm{PBTL}=(\mathrm{BTL} / \mathrm{BD}) \mathrm{X} 100 \%$

Dimana :

PBTL $=$ Proporsi belanja tidak langsung (persen)

BTL = Belanja tidak langsung (juta rupiah)

$\mathrm{BD}=$ Belanja daerah Kabupaten Tanjung Jabung Barat (juta rupiah)

Rumus proporsi belanja langsung:

$\mathrm{PBL}=(\mathrm{BL} / \mathrm{BD}) \mathrm{X} 100 \%$

Dimana :

PBL = Proporsi belanja langsung (persen)

$\mathrm{BL}=$ Belanja langsung (juta rupiah)

$\mathrm{BD}=$ Belanja daerah Kabupaten Tanjung Jabung Barat (juta rupiah)

Untuk menjawab tujuan kedua dari penelitian ini, menurut Musgrave (2001) dalam mengukur kemampuan fiskal keuangan daerah dapat digunakan derajat desentralisasi fiskal antara pemerintah pusat dan daerah antara lain :

Rumus derajat desentralisasi fiskal (DFF):

$\mathrm{DDF}=(\mathrm{PAD} / \mathrm{TPD}) \mathrm{X} 100 \%$

Dimana :

DDF $=$ Derajat desentralisasi fiskal (persen)

PAD $=$ Pendapatan asli daerah Kabupaten Tanjung Jabung Barat (juta rupiah)

$\mathrm{TPD}=$ Total penerimaan daerah Kabupaten Tanjung Jabung Barat (juta rupiah) 
Selain itu, untuk menjawab tujuan ketiga dalam melihat kemandirian keuangan daerah dapat menggunakan derajat kemandirian daerah untuk mengukur seberapa jauh penerimaan yang berasal dari daerah dalam memenuhi kebutuhan daerah (Halim, 2001), antara lain :

Rumus rasio kemandirian keuangan daerah:

$\mathrm{KKD}=(\mathrm{PAD} / \mathrm{PP}) \mathrm{X} 100 \%$

Dimana :

KKD = Kemampuan keuangan daerah (persen)

$\mathrm{PAD} \quad=$ Pendapatan asli daerah Kabupaten Tanjung Jabung Barat (juta rupiah)

PP = Dana perimbangan (juta rupiah)

Untuk menganalisis tujuan keempat dalam melihat kinerja Keuangan pemerintah Kabupaten Tanjung Jabung Barat dilihat dari kemampuan PAD dalam membiayai belanja Tidak langsung dan belanja langsung maka digunakan rumus IKBR (Indeks Kemampuan Belanja Tidak langsung / langsung yang diukur dalam persentase) dengan formulasi :

Rumus indeks kemampuan belanja tidak langsung (IKBTL)

$\mathrm{IKBTL}=\frac{\sum \text { PAD }}{\sum \text { Belanja tidak langsung }} X 100$ persen

Rumus indeks kemampuan belanja langsung (IKBL)

$\mathrm{IKBL}=\frac{\sum \text { PAD }}{\sum \text { Belanja langsung }} X 100$ persen

Dimana :

IKBTL /IKBL $\quad 0,00$ persen $-10,00$ persen; kriteria sangat kurang,

IKBTL /IKBL 10,01 persen - 20,00 persen; kriteria kurang,

IKBTL /IKBL 20,01 persen - 30,00 persen; kriteria sedang,

IKBTL /IKBL 30,10 persen - 40,00 persen; kriteria cukup

IKBTL /IKBL 40,01 persen - 50,00 persen; kriteria baik, dan

IKBTL /IKBL > 50,00 persen kriteria sangat baik,

Untuk menjawab tujuan kelima dari penelitian ini yaitu melihat pengaruh antara belanja daerah dengan pertumbuhan ekonomi daerah digunakan analisis regresi linear sederhana dengan rumus :

$$
P E t=\beta 0 t+\beta 1 B D t+\mu t
$$

Keterangan:

$\mathrm{PE} \quad=$ Pertumbuhan ekonomi dari produk domestik regional bruto (Persen)

$\mathrm{BD}=$ Belanja daerah Kabupaten Tanjung Jabung Barat (Juta Rupiah)

$\beta 0=$ Konstanta

$\beta 1=$ koefisien regresi untuk masing-masing variabel bebas

$\mu \quad=$ Standar error

$\mathrm{t}=$ Waktu

Log = Logaritma 


\section{Uji hipotesis}

Uji hipotesis secara statistik, setidaknya ini dapat diukur dari nilai statistik $\mathrm{t}$ dan nilai koefisien determinasi. Perhitungan statistik disebut signifikan secara statistik apabila nilai uji statistiknya berada dalam daerah kritis (daerah dimana Ho ditolak). Sebaliknya disebut tidak signifikan bila nilai uji statistiknya berada dalam daerah dimana Ho diterima (Ghozali, 2006).

\section{Uji signifikansi parameter individual (Uji Statistik t)}

Uji t dilakukan untuk menguji signifikansi yang ditaksir sebagai pengaruh antara variabel bebas terhadap variabel terikat, digunakan uji t statistik (t-test) dengan rumus sebagai berikut :

$$
t_{\text {hitung }}=\frac{\alpha_{1}}{S e\left(\alpha_{1}\right)}
$$

Dimana :

$$
\begin{aligned}
\mathrm{t} & =\mathrm{t}-\text { hitung } \\
\alpha_{1} & =\text { Koefisien regresi } \\
\mathrm{Se} & =\text { Standar Error. }
\end{aligned}
$$

Uji t dilakukan untuk melihat signifikansi dari pengaruh variabel bebas secara individual terhadap variabel terikat dengan menganggap variabel bebas lainnya adalah konstan. Pada tingkat signifikansi 5 persen dengan pengujian yang digunakan adalah sebagai berikut : $\mathrm{H}_{0}$ ditolak $\mathrm{H}_{1}$ diterima apabila $\mathrm{t}$ hitung $>\mathrm{t}$ tabel, yang berarti variabel independennya berpengaruh secara signifikan terhadap variabel dependen.

\section{Koefisien determinasi $\left(\mathbf{R}^{\mathbf{2}}\right)$}

Koefisien determinasi $\mathrm{R}^{2}$ pada intinya mengukur seberapa jauh kemampuan model dalam menerangkan variasi variabel independent. Nilai koefisien determinasi di antara 0 dan $1\left(0<\mathrm{R}^{2}<1\right)$, nilai $\left(\mathrm{R}^{2}\right)$ yang kecil berarti kemampuan variabel-variabel independen dalam menjelaskan variasi variabel independent sangat terbatas. Nilai yang mendekati 1 berarti variabel independent memberikan hampir semua informasi yang dibutuhkan untuk memperoleh prediksi variasi model dependent. Semakin tinggi nilai koefisien determinasi maka akan semakin baik pula kemampuan variabel independen dalam menjelaskan variabel dependen.

\section{HASIL DAN PEMBAHASAN}

\section{Proporsi belanja tidak langsung terhadap belanja daerah Kabupaten Tanjung Jabung Barat}

Kelompok belanja tidak langsung, merupakan belanja yang dianggarkan tidak terkait secara langsung dengan pelaksanaan program dan kegiatan, yaitu belanja pegawai, belanja bunga, belanja subsidi, belanja hibah, belanja bantuan sosial, belanja bagi hasil, belanja bantuan keuangan, dan belanja tidak terduga. Keberadaan Belanja Tidak Langsung bukan merupakan konsekuensi dan atau tiada suatu program atau kegiatan. Belanja Tidak Langsung digunakan secara periodik (umumnya bulanan) dalam rangka koordinasi penyelenggaraan kewenangan pemerintah Daerah yang bersifat umum. Adapun proposi belanja tidak langsung terhadap belanja daerah terlihat pda tabel 1. 
Tabel 1. Proporsi belanja tidak langsung terhadap belanja daerah Kabupaten Tanjung Jabung Barat Tahun 2005-2015

\begin{tabular}{cccc}
\hline Tahun & $\begin{array}{c}\text { Belanja tidak langsung (Ribu } \\
\text { Rupiah) }\end{array}$ & $\begin{array}{c}\text { Belanja daerah } \\
\text { (Ribu Rupiah) }\end{array}$ & $\begin{array}{c}\text { Proporsi } \\
(\mathbf{\%})\end{array}$ \\
\hline 2005 & $112,273.19$ & $190,052.36$ & 59.07 \\
2006 & $153,446.55$ & $302,571.88$ & 50.71 \\
2007 & $147,384.37$ & $472,860.65$ & 31.17 \\
2008 & $188,658.54$ & $550,481.43$ & 34.27 \\
2009 & $252,898.87$ & $641,315.77$ & 39.43 \\
2010 & $314,643.38$ & $639,079.89$ & 49.23 \\
2011 & $351,375.16$ & $731,332.59$ & 48.05 \\
2012 & $329,179.51$ & $814,224.54$ & 40.43 \\
2013 & $402,214.46$ & $1,279,626.01$ & 31.43 \\
2014 & $499,378.93$ & $1,480,568.98$ & 33.73 \\
2015 & $595,972.97$ & $1,574,888.40$ & 37.84 \\
\hline Rata-rata & $\mathbf{3 0 4 , 3 1 1 . 4 5}$ & $\mathbf{7 8 8 , 8 1 8 . 4 1}$ & $\mathbf{3 8 . 5 8}$ \\
\hline
\end{tabular}

Sumber: BPS, diolah

Berdasarkan Tabel 1, proporsi belanja tidak langsung cenderung mengalami penurunan. Proporsi tertinggi terjadi pada tahun 2005 yaitu sebesar 59,07\% sedangkan proporsi terendah terjadi pada tahun 2007 yaitu sebesar 31,17\%.

\section{Proporsi belanja langsung terhadap belanja daerah Kabupaten Tanjung Jabung Barat}

Kelompok belanja langsung merupakan belanja yang dianggarkan terkait secara langsung dengan pelaksanaan program dan kegiatan yaitu belanja pegawai, belanja barang dan jasa, dan belanja modal. Adapun proporsi belanja langsung terhadap belanja daerah Kabupaten Tanjung Jabung Barat tahun 2005 sampai 2015 dapat dilihat pada tabel 2.

Tabel 2.Proporsi belanja langsung terhadap belanja daerah kabupaten tanjung jabung barat tahun 2005-2015

\begin{tabular}{cccc}
\hline Tahun & $\begin{array}{c}\text { Belanja langsung } \\
\text { (Ribu Rupiah) }\end{array}$ & $\begin{array}{c}\text { Belanja daerah } \\
\text { (Ribu Rupiah) }\end{array}$ & $\begin{array}{c}\text { Proporsi } \\
(\mathbf{\%})\end{array}$ \\
\hline 2005 & $112,273.19$ & $190,052.36$ & 40.93 \\
2006 & $153,446.55$ & $302,571.88$ & 49.29 \\
2007 & $147,384.37$ & $472,860.65$ & 68.83 \\
2008 & $188,658.54$ & $550,481.43$ & 65.73 \\
2009 & $252,898.87$ & $641,315.77$ & 60.57 \\
2010 & $314,643.38$ & $639,079.89$ & 50.77 \\
2011 & $351,375.16$ & $731,332.59$ & 51.95 \\
2012 & $329,179.51$ & $814,224.54$ & 59.57 \\
2013 & $402,214.46$ & $1,279,626.01$ & 68.57 \\
2014 & $499,378.93$ & $1,480,568.98$ & 66.27 \\
2015 & $595,972.97$ & $1,574,888.40$ & 62.16 \\
\hline Rata-rata & $\mathbf{3 0 4 , 3 1 1 . 4 5}$ & $\mathbf{7 8 8 , 8 1 8 . 4 1}$ & $\mathbf{6 1 . 4 2}$ \\
\hline
\end{tabular}

Sumber: BPS,diolah

Berdasarkan Tabel 2 terlihat bahwa proporsi tertinggi terjadi pada tahun 2007 yaitu sebesar $68,83 \%$ sedangkan proporsi terendah terjadi pada tahun 2005 yaitu sebesar 
40,93\%. Terhitung dari 2010-2015, terlihat bahwa proporsi belanja langsung sudah lebih dari 50\% dari total belanja daerah Kabupaten Tanjung Jabung Barat. Hal ini tergolong baik karena terkait langsung dengan kegaitan seperti belanja pegawai, belanja modal dan jasa. Alokasi belanja langsung yang semakin besar akan dapat meningkatkan pertumbuhan ekonomi secara tidak langsung. Sebaiknya belanja langsung berupa belanja maodal dapat ditujukan untuk belanja modal yang terkait langsung dengan belanja modal ekonomi masyarakat dan ekonomi daerah seperti dana untuk pelabuhan , jalan dan sebagainya.

\section{Kemampuan fiskal Kabupaten Tanjung Jabung Barat}

Kapasitas fiskal menunjukkan kemampuan daerah dalam membiayai sendiri kegiatan pemerintahan, pembangunan, dan pelayanan kepada masyarakat yang telah membayar pajak dan retribusi sebagai sumber pendapatan yang diperlukan daerah. Desentralisasi fiskal diyakini akan meningkatkan kesejahteraan masyarakat, karena adanya kebutuhan masyarakat daerah terhadap pendidikan dan barang publik pada umumnya akan terpenuhi dengan lebih baik dibandingkan bila diatur langsung oleh pemerintah pusat. Kemampuan Fiskal Kabupaten Tanjung Jabung Barat dapat dilihat pada Tabel 3

Tabel 3. Kemampuan fiskal Kabupaten Tanjung Jabung Barat tahun 2005-2015

\begin{tabular}{cccc}
\hline Tahun & $\begin{array}{c}\text { Pendapatan asli daerah } \\
\text { (Ribu Rupiah) }\end{array}$ & $\begin{array}{c}\text { Total pendapatan daerah } \\
\text { (Ribu Rupiah) }\end{array}$ & $\begin{array}{c}\text { DDF } \\
(\%)\end{array}$ \\
\hline 2005 & $13,802.71$ & $261,231.45$ & 5.28 \\
2006 & $18,134.03$ & $452,144.75$ & 4.01 \\
2007 & $19,076.37$ & $510,687.52$ & 3.74 \\
2008 & $20,854.55$ & $521,094.00$ & 4.00 \\
2009 & $17,886.00$ & 554,759 & 3.22 \\
2010 & $21,838.29$ & 494,709 & 4.41 \\
2011 & $22,451.35$ & 635,164 & 3.53 \\
2012 & $29,727.55$ & 761,628 & 3.90 \\
2013 & $43,683.41$ & 941,040 & 4.64 \\
2014 & $57,163.26$ & $1,158,859$ & 4.93 \\
2015 & $71,943.82$ & $1,274,925$ & 5.64 \\
\hline Rata-Rata & $\mathbf{3 0 , 5 9 6 . 4 9}$ & $\mathbf{6 8 7 , 8 4 0 . 1 6}$ & $\mathbf{4 . 3 0}$ \\
\hline
\end{tabular}

Sumber: BPS, diolah

Berdasarkan Tabel 3 terlihat bahwa kemampuan fiskal Kabupaten Tanjung Jabung Barat selama 11 tahun masih dalam skala interval yang sangat kurang. Hal ini disebabkan karena nilai DDF berada diantara skala interval 0\%-10\%. Hal ini berarti bahwa PAD Kabupaten Tanjun Jabung Barat mempunyak kemampuan yang sangat kurang dalam membiayai pembangunan daerah. Hal ini disebabkan karena nilai PAD yang lebih kecil dibandingkan dengan Total Pendapatan Daerah. Pemerintah daerah memiliki kebijakan peningkatan PAD. Peningkatan kinerja manajemen dan keuangan BUMD (seperti Tirata pengabuan, Bank Tanggo Rajo) akan meningkatan pajak dan retribusi yang relative baik tetapi kebijakan ini akan berdampak pada sisi buruk yakni iklim ekonomi yang tidak kondusif bagi masyarakat. Oleh karena itu akab banyak beban pungutan terhadap masyarakat. 


\section{Rasio kemandirian keuangan daerah}

Kemandirian keuangan daerah menunjukkan kemampuan Pemerintah Daerah dalam membiayai kegiatan pemerintahan, pembangunan dan pelayanan kepada masyarakat yang telah membayar pajak dan retribusi sebagai sumber yang diperlukan daerah. Kemandirian keuangan daerah dapat dilihat besarnya PAD dibandingkan dengan penerimaan transfer dari pusat. PAD merupakan unsur utama dalam mengukur kemandirian keuangan daerah. PAD merupakan semua penerimaan daerah yang berasal dari sumber ekonomi asli daerah. PAD bersumber dari hasil pajak daerah, hasil retribusi daerah, hasil pengelolaan kekayaan daerah yang dipisahkan, dan pendapatan lain asli daerah yang sah yang bertujuan untuk mencapai daerah yang mandiri.

Tabel 4. Rasio kemandirian daerah Kabupaten Tanjung Jabung Barat tahun 2005-2015

\begin{tabular}{cccc}
\hline Tahun & $\begin{array}{c}\text { Pendapatan asli daerah } \\
\text { (Ribu Rupiah) }\end{array}$ & $\begin{array}{c}\text { Dana perimbangan } \\
\text { (Ribu Rupiah) }\end{array}$ & $\begin{array}{c}\text { KKD } \\
(\boldsymbol{\%})\end{array}$ \\
\hline 2005 & $13,802.71$ & $232,269.09$ & 5.94 \\
2006 & $18,134.03$ & $413,580.72$ & 4.38 \\
2007 & $19,076.37$ & $477,743.54$ & 3.99 \\
2008 & $20,854.55$ & $489,568.61$ & 4.26 \\
2009 & $17,886.00$ & $520,739.00$ & 3.43 \\
2010 & $21,838.29$ & $445,947.38$ & 4.90 \\
2011 & $22,451.35$ & $558,052.29$ & 4.02 \\
2012 & $29,727.55$ & $681,869.45$ & 4.36 \\
2013 & $43,683.41$ & $803,747.08$ & 5.43 \\
2014 & $57,163.26$ & $1,010,704.60$ & 5.66 \\
2015 & $71,943.82$ & $1,080,883.44$ & 6.66 \\
\hline Rata-rata & $\mathbf{3 0 , 5 9 6 . 4 9}$ & $\mathbf{6 1 0 , 4 6 4 . 1 1}$ & $\mathbf{4 . 8 2}$ \\
\hline Sumber: BPS, diolah & & &
\end{tabular}

Berdasarkan Tabel 4, terlihat bahwa rasio kemandirian daerah Kabupaten Tanjung Jabung Barat selama dari tahun 2005-2015 tergolong ke dalam kriteria rendah sekali. Hal ini ditunjukkan oleh nilai KKD yang berada pada skala interval 0\%-25\%. Hal ini menunjukkan bahwa Kabupaten Tanjung Jabung Barat memiliki ketergantungan yang sangat tinggi terhadap bantuan dari pemerintah pusat melalui dana perimbangan dalam melaksanakan otonomi daerah dan desentralisasi fiskal atau peranan pemerintah pusat lebih dominan daripada daerah.

Kinerja peningkatan sumber-sumber PAD harus dilakukan memalui kajian yang tepat seperti efisien dan efektifitas. Bisa saa terjadisebuah sumber penerimaan PAD dapat selalu efisien dan efekktif. Akan tetapi, kinera keuangandari OPD (Organisasi Perangkat Desa) relative kurang baik. Sebaiknya,penentuan target penerimaan PAD secara perlahansudah dimulai dari potensi PAD terlebih dahulu.

\section{Kinerja keuangan pemerintah daerah}

Kinerja keuangan pemerintah daerah adalah tingkat pencapaian dari suatu hasil kerja di bidang keuangan daerah yang meliputi peneriman dan belanja daerah dengan menggunakan sistem keuangan yang ditentukan melalui suatu kebijakan atau ketentuan perundang-undangan selama satu periode anggaran. Kinerja Keuangan pemerintah Kabupaten Tanjung Jabung Barat dapat dilihat dari kemampuan PAD dalam membiayai belanja tidak langsung dan belanja langsung. 


\section{Indeks kemampuan belanja tidak langsung}

Indeks kemampuan belanja tidak langsung merupakan rasio antara pendapatan asli daerah dalam membiayai belanja tidak langsung Kabupaten Tanjung Jabung Barat. Indeks Kemampuan Belanja Tidak Langsung dapat dilihat pada tabel 5.

Tabel 5. Indeks kemampuan belanja tidak langsung

\begin{tabular}{cccc}
\hline Tahun & $\begin{array}{c}\text { Pendapatan asli daerah } \\
\text { (Ribu Rupiah) }\end{array}$ & $\begin{array}{c}\text { Belanja tidak langsung } \\
\text { (Ribu Rupiah) }\end{array}$ & $\begin{array}{c}\text { IKBTL } \\
(\boldsymbol{\%})\end{array}$ \\
\hline 2005 & 13802.71 & 112273.19 & 12.29 \\
2006 & 18134.03 & 153446.55 & 11.82 \\
2007 & 19076.37 & 147384.37 & 12.94 \\
2008 & 20854.55 & 188658.54 & 11.05 \\
2009 & 17886.00 & 252898.87 & 7.07 \\
2010 & 21838.29 & 314643.38 & 6.94 \\
2011 & 22451.35 & 351375.16 & 6.39 \\
2012 & 29727.55 & 329179.51 & 9.03 \\
2013 & 43683.41 & 402214.46 & 10.86 \\
2014 & 57163.26 & 499378.93 & 11.45 \\
2015 & 71943.82 & 595972.97 & 12.07 \\
\hline Rata-rata & $\mathbf{3 0 5 9 6 . 4 9}$ & $\mathbf{3 0 4 3 1 1 . 4 5}$ & $\mathbf{1 0 . 1 7}$ \\
\hline Sumber: BPS, diolah & & &
\end{tabular}

Berdasarkan Tabel 5, terlihat bahwa indek kemampuan belanja tidak langsung tergolong ke dalam skala interval kurang. Hal ini terlihat dari rata-rata nilai IKBTL adalah 10,17 yang berada diantara skala interval 10,01-20,00\%. Hal ini disebabkan karena nilai PAD yang lebih kecil dibandingkan dengan nilai belanja tidak langsung.

\section{Indeks kemampuan belanja langsung}

Indeks kemampuan belanja langsung merupakan rasio antara pendapatan asli daerah dalam membiayai belanja langsung Kabupaten Tanjung Jabung Barat. Indeks Kemampuan Belanja Langsung dapat dilihat pada Tabel 6.

Tabel 6. Indeks kemampuan belanja langsung

\begin{tabular}{cccc}
\hline Tahun & $\begin{array}{c}\text { Pendapatan asli daerah } \\
\text { (Ribu Rupiah) }\end{array}$ & $\begin{array}{c}\text { Belanja langsung } \\
\text { (Ribu Rupiah) }\end{array}$ & $\begin{array}{c}\text { Kinerja } \\
(\boldsymbol{\%})\end{array}$ \\
\hline 2005 & 13802.71 & 77779.17 & 17.75 \\
2006 & 18134.03 & 149125.33 & 12.16 \\
2007 & 19076.37 & 325476.28 & 5.86 \\
2008 & 20854.55 & 361822.89 & 5.76 \\
2009 & 17886.00 & 388416.91 & 4.60 \\
2010 & 21838.29 & 324436.51 & 6.73 \\
2011 & 22451.35 & 379957.43 & 5.91 \\
2012 & 29727.55 & 485045.03 & 6.13 \\
2013 & 43683.41 & 877411.55 & 4.98 \\
2014 & 57163.26 & 981190.05 & 5.83 \\
2015 & 71943.82 & 978915.43 & 7.35 \\
\hline Rata-rata & $\mathbf{3 0 5 9 6 . 4 9}$ & $\mathbf{4 8 4 5 0 6 . 9 6}$ & $\mathbf{7 . 5 5}$ \\
\hline Suta
\end{tabular}

Sumber: BPS,2016 (diolah)

Berdasarkan Tabel 6, terlihat bahwa indek kemampuan belanja tidak langsung tergolong ke dalam skala interval sangat kurang. Hal ini terlihat dari rata-rata nilai IKBTL adalah 7,55 yang berada diantara skala interval $0,00-10,00 \%$. Hal ini 
disebabkan karena nilai PAD yang lebih kecil dibandingkan dengan nilai Belanja Langsung

\section{Pengaruh belanja daerah terhadap perekonomian di Kabupaten Tanjung Jabung Barat}

Pengaruh Belanja Daerah terhadap Perekonomian di Kabupaten Tanjung Jabung Barat dapat diukur dengan regresi linier sederhana dengan bantuan program Eviews 7.0. Variabel yang digunakan adalah Pertumbuhan Ekonomi (PE) sebagai variabel terikat dan Belanja Daerah (BD) sebagai variabel bebas. Hasil output regresi linier sederhana dapat dilihat pada Tabel 7.

Tabel 7. Hasil regresi linier sederhana

\begin{tabular}{lccrr}
\hline \multicolumn{1}{c}{ Variable } & Coefficient & Std. error & t-Statistik & Prob. \\
\hline C & 1791102. & 70533.97 & 25.39346 & 0.0000 \\
BD & 0.764725 & 0.078058 & 9.796882 & 0.0000 \\
R-squared & 0.914268 F-statistic & & 95.97890 \\
F-statistic & 95.97890 Prob(F-statistic) & & 0.000004 \\
Prob(F-statistic) & 0.000004 & & \\
\hline
\end{tabular}

Sumber: Data diolah, 2016

Berdasarkan Tabel 7 didapat persamaan regresi dari variabel Pertumbuhan Ekonomi (PE) sebagai variabel terikat dan Belanja Daerah (BD) sebagai variabel bebas adalah sebagai berikut:

$$
\mathrm{PE}=1791102+0.764725 \mathrm{BD}
$$

Berdasarkan persamaan regresi tersebut maka bisa dijelaskan bahwa apabila variabel Belanja Daerah (BD) tetap atau tidak berubah maka pertumbuhan ekonomi akan meningkat sebesar 1.791.102 juta rupiah atau 1,9 miliar rupiah. Berdasarkan persamaan tersebut terlihat bahwa apabila Belanja Daerah mengalami peningkatan maka Pertumbuhan ekonomi akan meningkat pula. Hal ini terlihat dari koefisien Belanja Daerah yang bernilai positif sehingga hubungan Belanja Daerah dan Pertumbuhan Ekonomi adalah positif.

\section{Pengujian hipotesis}

Tabel 7 menjelaskan bahwa terdapat pengaruh antara Belanja Daerah dan Pertumbuhan Ekonomi yang ditunjukkan oleh nilai probabilitas t-hitung yaitu 0.0000 yang lebih kecil dari tingkat signifikansi $5 \%(0,05)$.

\section{KESIMPULAN DAN SARAN}

\section{Kesimpulan}

Proporsi belanja tidak langsung terhadap belanja daerah cenderung mengalami penurunan sedangkan proporsi belanja langsung terhadap belanja daerah mengalami peningkatan. Kemampuan fiskal Kabupaten Tanjung Jabung Barat selama 11 tahun masih dalam skala interval yang sangat kurang. Kemandirian keuangan daerah Kabupaten Tanjung Jabung Barat berada pada kriteria rendah. Kinerja keungan daerah Kabupaten Tanjung Jabung Barat berada dalam kriteria rendah dan sangat rendah. Belanja Daerah memiliki pengaruh terhadap pertumbuhan ekonomi di Kabupaten Tanjung Jabung Barat. 


\section{Saran}

Para akademis yang tertarik untuk meneliti judul yang sama diharapkan agar melakukan penelitian dengan menggunakan alat analisis yang lain yang dapat menjelaskan hubungan yang signifikan tentang pertumbuhan ekonomi di Kabupaten Tanjung Jabung Barat.

\section{DAFTAR PUSTAKA}

A Bhakti. (2013).Deteksi Ilusi Fiskal Kabupaten/Kota di Provinsi Jambi (Pengujian Perilaku Asimetris Pemerintah Daerah dalam Merespon Dana Perimbangan), Jurnal Perspektif Pembiayaan Dan Pembangunan Daerah 1 (2), 71-80

Alfin Lains. (2005). Pendapatan daerah dalam ekonomi orde baru, Prisma No. 4, Jakarta.

Arsyad Lincolyn. (2002). Pengantar perencanaan dan pembangunan ekonomi daerah Yogyakarta : BPFE.

Asrori, B. S.(1999). Faktor-faktor yang mempengaruhi kemampuan untuk melaksanakan otonomi daerah di Yogyakarta. Tesis, MAP UGM Yogyakarta, (Tidak Dipublikasikan).

Atkinson, A.B, dan Stiglitz, J.E. (1999). Lectures on public economic, Mc Graw-Hill, Book Company.

Bachrul Elmi. (2002). Keuangan pemerintah daerah otonom di Indonesia. Skripsi Fakultas Ekonomi Universitas Indonesia: Jakarta.

Bahl, Roy. W. (2002). Fiscal Decentralization In Indonesia : The fisrt year in review and the challenges ahead, IRIS, University of Maryland at College Park.

Boediono, 2003. Seri Sinopsis, Pengantar Ilmu Ekonomi, Ekonomi Mikro, BPFE, Yogyakarta.

Davey. K.Y. (2003). Pembiayaan pemerintahan daerah praktek-praktek internasional dan relevansinya bagi dunia ketiga, dalam skripsi Fakultas Ekonomi Universitas Indonesia, Jakarta.

Devas, Nick, dkk. (1999). Keuangan pemerintahan daerah di Jakarta. Skripsi. Fakultas Ekonomi Universitas Indonesia :

Gunawan Sumodiningrat. (2006). Ekonometrika pengantar, FE. UGM, Yogyakarta.

H.A.W. Wijaya, 2002. Otonomi daerah dan daerah otonom, PT. Raja Grafindo Persada, Jakarta.

Ibnu Syamsi. (2004). Dasar-dasar kebijaksanaan keuangan negara, Edisi Revisi. PT. Rineka Cipta, Jakarta.

Josef Riwu Kaho. (2001). Prospek otonomi daerah di negara Republik Indonesia, PT. Raja Grafindo Persada, Jakarta.

Koeswara, E. (2000). Menyongsong pelaksanaan otonomi daerah berdasarkan UU No. 22 Tahun 1999. Analisis CSIS No. I Tahun XXIX.

Kuncoro, Mudrajad 2005. Mudrajat. "Ekonomi Pembangunan : Teori, Masalahmasalah dan Kebijakan”, UPP-AMP YKPN, Yogyakarta.

Kuncoro, Mudrajad. (2005). Otonomi daerah dan Pembangunan daerah :Reformasi, Perencanaan, Strategis dan Peluang. Erlangga, Jakarta.

Lewis B. (2004). Tax and Charge Creation By Local Government, Bulletin of Indonesian Economic Studies,

Mahi, R. (2004). Prospek desentralisasi di Indonesia ditinjau dari segi pemerataan antar daerah dan peningkatan efisiensi, Analisis CSIS No. 1 Tahun XXIX, Jakarta. 
Manullang, M. (2001). Beberapa aspek administrasi pemerintah daerah”, Penerbit Ghalia Indonesia, Jakarta.

Mardiasmo. (2002). Otonomi dan manajemen keuangan daerah, Andi, Yogyakarta.

Mc Cann P. (2006). Urban dan Regional Economis, Oxford University Press, New York.

Musgrave, Richard. A. (2003). Musgrave Peggy. B, Keuangan negara dalam teori dan praktek, Erlangga, Jakarta .

Radianto. (2007). Studi Kebutuhan Kuantitas dan Kualitas SDM untuk Sektor-Sektor Unggulan di Kapet Seram-Maluku, Jurnal ekonomi dan bisnis Indonesia vol 10 nomor 1, BPFE, Yogyakarta,

S Rahmadi, M Safri. (2014).Peningkatan Belanja Modal dan Hubungannya terhadap Peningkatan Belanja Aset dan PAD Provinsi Jambi, Jurnal Paradigma Ekonomika 9 (1)

Sach, Jeffery, D and Larrian, B.Felipe. (2002). Macroeconomics in the Global Economy. Harvester Wheatsheat, Singapore.

Sanit, Arbi. (2004). Format otonomi daerah reformatif , Makalah Seminar Sehari Ikatan Mahasiswa Ilmu Pemerintahan, dengan Tema : Format Otonomi Daerah Masa Depan, Sekolah Tinggi Pembangunan Masyarakat Desa “APMD”.

Sidik, Machfud. (2002). Perimbangan keuangan pusat dan daerah sebagai pelaksanaaan desentralisasi fiskal. Makalah seminar setahun implementasi kebijaksanaaan otonomi daerah di Indonesia, Yogyakarta.

Singarimbin Masri. (2002). Otonomi dan manajemen keuangan daerah, Andi, Yogyakarta . 